\title{
The Effect of Mobile Banking Application on Customer Interaction in the Jordanian Banking Industry
}

\author{
https://doi.org/10.3991/ijim.v13i02.9262 \\ Khaled Aldiabat $\left({ }^{\square}\right)$ \\ Ajloun National University, Ajloun, Jordan \\ khaledmis@yahoo.com \\ Anwar Al-Gasaymeh \\ Applied Science Private University, Amman, Jordan \\ Ameer Sardar Kwekha Rashid \\ University of Sulaimani, Sulaimani-Iraq
}

\begin{abstract}
Banks have changed from paper-based banking solutions provider to the latest of the technologies like mobile banking. Adoption of mobile-banking has received more attention in recent years, because there are more phones than computers in the market. But, like in any emerging technology, there exist barriers to the adoption of mobile banking services. This study will attempt to technically address these largely unfounded factors while helping to lay a roadmap for proper implementation of mobile banking technology in the Jordanian banking industry. The study found that Supportive Access factor of mobile banking is associated with the user satisfaction related to mobile banking.
\end{abstract}

Keywords—Mobile Banking; Reliability; Quality of service; Credibility and security, Customers interaction, Ease of use

\section{Introduction}

In the recent year's mobile banking, mobile commerce, and other systems have been treated as innovations and self-service technologies among customers who adopted such technologies [1]. Consequently, recent research showed that banks emphasized the benefits of such new application in an effort to increase customers' satisfaction and decrease bank's expenses [2][3]. Mobile banking evolved when financial institutions (especially banks) began to offer their operations online. This new approach provides many advantages for service providers such as allowing the bank to be free of restrictions to specific geographical areas, so they operate in new market places, expand delivery options, improve performance, increase customers' loyalty, and reduce cost of operations. Also, customers benefit from a customized and personalized service, and a reduction in wait time for the sake of more convenient service $[4][5][6][7]$. Beside the benefits and advantages of utilizing Mobile banking, 
the quality of service related to the Mobile banking attracted much research. Researchers focused on understanding how banking institutions are trying to make customers happy and how to make them more loyal. They investigated users' acceptance and satisfaction of Mobile banking based on the quality of services provided and the factors related to it [8].

Online banking is interesting social media categories for the Context Engine or recommender systems due to the number of practical applications. Interesting sources of information might be foursquare, twitter, LinkedIn and Wikipedia. In particular, open social media platforms, which offer open content without authentication, are of particular interest, some examples being twitter, Flickr or YouTube. Although social media is a rich source of information, there are two issues that hinder its development that are, in essence, the same as with virtual information but more accentuated: First, the need to cope with information in non-machine readable formats, such as plaintext, for which advanced data and text mining techniques should be developed further. Second, the closeness or unavailability of the data matters: service providers may choose not to disclose such information, often vital in their business models [9].

There are many studies have shown that, the adoption of mobile banking has been steadily growing with increased innovation and product offerings [9]. The adoption has depended on the spread of mobile phones, which has created a countrywide accessibility of the services, security reliability, and effectiveness of mobile money transfer [10]. The adoption of mobile money is steadily growing in businesses [11]. Most businesses now carry out large financial transactions via mobile banking platforms. However, one of the key issues evident it the cost of setting up mobile money services for organizations. In the previous studies, knowledge gaps exist since there are numerous factors that affect customer satisfaction when using mobile banking that have yet to be identified. One of the major gaps is the number of features that a mobile banking application has. The more the number of features that a mobile banking application has, the more transactions that a customer can carry out and therefore they are likely to be more satisfied with the product. Reliability is another major gap not examined in the previous research that affects customer satisfaction in mobile banking in Jordan. Although mobile banking products are available from many providers, their reliability is usually questionable. Most mobile platforms have experienced outages of some sort, which can be very inconveniencing for customers. Another gap is communication problems between the application and the bank's servers can sometimes also be unreliable inconveniencing users in the process. As observed, most of the studies carried out in this area have focused on the adoption of mobile banking technologies by the population. Previous authors have conducted studies regarding the factors that affect the adoption of mobile banking. For instance, in its infancy, the few banks offering the service limited adoption of mobile banking. Security concerns have also affected the adoption of mobile banking [12]. However, few if any studies have been carried out to determine the customer satisfaction when using these services.

This study is therefore, significant in defining the adoption of the mobile banking applications in Jordan, from the fact that few studies have been conducted in explaining its impact on clientele satisfaction. The design of mobile banking 
applications is another gap in research that also plays a major role in customer satisfaction. The applications have to be intuitive and easy to use. It is important to consider that most of these applications will be used on mobile devices with small screens. Many mobile banking applications also have features that do not work properly or not at all. This is a result of poor design and implementation of the application. Many mobile banking applications although convenient for the customer can be difficult to use. Even though a customer is able to use the application, the experience itself will not be satisfying to the customer. It is therefore important to interrogate the factors since they directly contribute to ease of use of mobile banking products, e-service quality, technological proficiency, and consumer attitudes, which in turn affect customer satisfaction when using mobile banking services and applications. Therefore, this study aimed at understanding and explaining a number of characteristics involved with the adoption and use of mobile banking applications by the people of Jordan and their effects on satisfaction.

\section{$2 \quad$ Literature Review}

The way banks have been delivering the services to their customers has been transformed by the explosive growth of Information and Communication Technologies with the financial industry especially the banking sector. Customers do their banking activities such as checking their account balances, doing payments, applying for credits, and transactions by means of hand-held devices via m-banking model which is a dynamic dealing channel of banks. Although having many inherent benefits with itself, the m-banking has been suffering from low and slower adoption by customers making this a vital issue to be studied and explained by many studies under various context globally. In recent years, many foreign and domestic scholars have used different theories and methods to carry out effective research on trustrelated issues, and put forward many trust evaluation models, social norms and other important trust structures. As for the extension of mobile banking, in previous research on the consumer demographic characteristics.

[13] Sought to determine the impact of mobile and internet-banking on performance of financial institutions in Kenya where the survey was conducted on financial institutions in Nairobi. The study also sought to identify the extent of use of mobile and internet banking in financial institutions. The study investigated 30 financial institutions. The study found that the most prevalent internet banking service is balance inquiry while the least is online bill payment. Cash withdrawal was the most commonly used mobile banking service whereas purchasing commodities was the least commonly used. Moreover, they found that mobile banking faces various challenges among them being, system delays by the mobile money transfer service providers, slow processing of transactions especially during the weekends, high transactions costs, limit on the amount of money that can be withdrawn in a day and fraud. These challenges can be solved through regular maintenance of mobile money transfer systems which will help in managing the systems' capacity and in turn address the problem of transaction delays and improve customer service through 
speedy support and lower user charges. [14] Aimed at exploring the influence of the factors adopted from the SERVQUAL model and extending with trust and security to predict customer satisfaction with Internet banking (IB). The study utilized a questionnaire to measure the research model utilizing a structural equation modeling technique. Results emphasized the role of security concerns, reliability and responsiveness in predicting the level of trust in IB. Also, trust was a significant predictor of satisfaction in IB services. Finally, the level of prediction yielded $22 \%$ of the variance in satisfaction. Also, customers depended on responsiveness, which means providing the required service, the proper assistance, and attaining customer's needs. Finally, security is important when dealing with financial transactions, and thus banks need to secure their systems against hackers and other vulnerabilities. This research emphasized the mediating role of trust in collecting all customers concerns and reflecting their influence on satisfaction.

Despite the growing interest from previous research, attitude towards mobile commerce in the context of mobile apps is also less explored. In addressing this, their study aims to provide an empirical blueprint that investigates consumers' attitude as the antecedents of mobile commerce and mobile commerce adoption through a fundamental framework by adapting the Technology Acceptance Model [15]. Contribute to the literature in two important ways. First, their study addresses the call for more research on individual-level variables as determinants of mobile commerce adoption. There is a paucity of research on consumer behavior based on TAM in emerging market, such as Malaysia.

[16] investigate the determinants that affect the adoption of mobile banking services in Jordan. Their study extended the Unified Theory of Acceptance and Use of Technology (UTAUT2) by adding two important factors, mass media and trust utilizing by seven respondents based on qualitative approach, their study show that the adoption of mobile banking is positively and significantly influenced by the mass media, trust, effort expectancy, performance expectancy, facilitating conditions, and social influence. In contrast, hedonic motivation seems to be insignificantly related to adoption of mobile banking services.

[17] Provided bank managers, a clear view of the relative performance of the various factors of the enterprise, which can be used to identify needed improvements and take advantage accordingly. Managers could periodically evaluate the factors in the study, benchmark the results with the expected satisfaction levels and diagnose which factors are problematic and need further consideration. The future designs will thereby form a clear understanding of business requirements, gain more vision and acquire ability to expand knowledge and skills to better assimilate and utilize mobile banking, and therefore minimize the risks associated. Taking into account the most important needs of the implementation; the architecture should be established well before the deployment. To ease the process; rigorous and sophisticated software testing should be performed. The results of the study revealed that Effective Distinctiveness, Professed Security, Immense Efficacy, Innovative Virtual Environment, Enhanced Personalization and Improved Timely Updates were not associated with satisfaction related to mobile banking while Supportive Access is an important factor which is directly associated with User Satisfaction related to mobile 
banking. This seems to be true since user did not find the importance of those features which are common to e-banking while the distinctive features of mobile banking were always given a priority. Supportive Access constituted of 2 factors knowledge integration and distinguished methodology. User did rightly gave a importance to these features because distinguished methodology helped the user to outweigh traditional banking features and the knowledge integration feature of mobile banking is the parameter which helps the user to give more priority to mobile banking. [18] Attaining a high rate of mobile banking adoption contributing towards the growth in the economy. Low cost driven Mobile banking channel will bring huge cost saving for the banking activities. Today, Banks and non-banks started to render financial services through mobile. This would in turn towards branchless mode of financial service leading to a greener society. However there is a risk of fraud and privacy issues which need a regulatory concern and also huge requirement of investment in the banking infrastructure. Trust is the most important concern in digital/mobile banking. Hence a study is made in Karnataka with sample size of 300 with a response rate of $40 \%$. Descriptive study was made to understand the relevance of various factors that influence or hinder the banking business through mobile. In this context, similar studies are reviewed to know the important variables of mobile banking adoption. TAM model is the most popular one in the study of technology based banking with perceived use and perceived ease of use variables. In the present study, TAM model was further extended with variables such as perceived cost, perceived risk, security and trust to get a better insight about the various influences in the usage of mobile banking. Reliability of the study was also measured. Perceived risk has shown negative influence in the usage of mobile banking. All other factors influence in the adoption of $\mathrm{m}$-banking. It is implicated to adopt the cost effective channel with increased level of protection to users of mobile banking. Region do not have a significant influence on various factors in the adoption of m-banking.

[19] Used empirical data from 434 users who had prior experience with m-banking were tested against the proposed research model by using structural equation modeling (SEM). The results indicate that satisfaction, perceived usefulness, perceived task-technology fit, and perceived risk are the main predictors of continuance intention, satisfaction, in turn, is determined by confirmation, perceived usefulness, and perceived risk. Perceived usefulness is affected by confirmation, perceived ease of use, and perceived task-technology fit. However, the direct effect of perceived ease of use to continuance intention is not significant. The results also show that gender significantly moderates the effect of perceived risk to continuance intention. Implications of the findings and future research directions are discussed. [20] Aimed to investigate factors influencing the acceptance of mobile banking in Libya. To assist in identifying these factors, a detailed research was carried out to identify the current problems faced by the Libyan banks customers, the acceptance of mobile banking in different countries around the world, the importance of adopting this technology to both parties: banks and customers in Libya. The sample elements consisted of 319 existing customers within the banking in Tripoli. They were selected at random depending on their willingness to participate in the research study. A survey was developed to obtain responses from various segments of the society. The 
findings showed that factors facilitating conditions, perceived self-Efficacy, Perceived ease of use, and perceived usefulness, and have significant impacts on consumer's behavioral intentions for the acceptance and usage of mobile banking technology in Libya.

[21] Studies several show factors that affect the trust mechanism of mobile banking, such as structure assurance, ubiquity, information quality, initial trust, perceived ease of use and experience. The results show that structure assurance is a most important factor influencing trust tendencies, and ubiquity, information quality, perceived satisfaction and perceived ease of use are some other key factors that affect initial trust and experience. The initial trust directly affects the users' sense of experience of mobile banking and decides the tendency of trust, which affects the actual use. Therefore, the mobile phone banks need to pay more attention to the initial sense of trust and experience to promote user acceptance and trust mobile banking services. The effects of sense of satisfaction on initial trust of mobile banking users are not pronounced. A reasonable explanation may be that domestic mobile communication operators and the support of mobile phone bank scale are relatively large, then their reputation are better in return; the quantity of users' payments has a direct and important influence on mobile banking trust, meaning that trust of mobile banking increases as the quantity of payment goes up, so plays an important role on use and promotion of mobile banking. [22] Aim to propose and empirically test a model that delineates the factors that influence banking customers' behavioral intention to use mobile banking (m-banking) services in Sri Lanka. Factors namely Perceived Usefulness (PU) and Perceived Ease of Use (PEOU) were based on popular Technology Acceptance Model (TAM) and Perceived Compatibility (PC) and Perceived Trust (PT) were adopted from literature since they appeared to be more contextual. Quantitative study based on questionnaire survey was adopted. Out of the 800 structured questionnaires administered using convenient sampling, 703 were returned and 695 were considered complete. Structural Equation Modelling was conducted to see the insights of the data collected from banking customers in Sri Lanka. The data collected excellently fitted the model proposed and the structural model confirmed that PU, PEOU, PC and PT, while PT being the strongest, significantly influence Sri Lankan banking customers' behavioral intention to use $\mathrm{m}$ banking services. While TAM factors are known to influence behavioral intention to use any technology, in Sri Lankan context, PT and PC have been empirically proved to influence customers' intention to use m-banking services. Actual adoption behavior and more factors including demographic controlling determinants could have been added to see more comprehensive insights. Although a plethora of works have already done to see intention to use and actual adoption of m-banking services, less is known in the case of Sri Lanka specifically attending to see Compatibility and Trust factors' influence on such intention. Hence, this study has attempted to bridge this gap incorporating these factors together with TAM factors and by empirically studying in Sri Lankan banking customers' context.

[23] Approach to understand various models of mobile banking and examine regulatory factors in South-Asian countries and in the nations where it is practiced so as to speed up the adoption rate quickly and successfully. It was suggested that banks 
and mobile operators should frame a solution and encourage new entries in the field. However, the major challenge is security and trust forcing convergence of banks and telecommunication sector. It was suggested to propose a model on grounds of modern approach so as to contribute to economic growth and development and give scope for encouragement and reward the innovation strategy.

\section{Methodology of the Study}

Based on the main objective of the study, which is to identify the extent to which customers in Jordanian banks interact with mobile banking applications in the process of managing the bank account as well as the benefit of these applications, and their understanding of the principle of the work of these applications, the study depended on the descriptive analytical approach to complete the study using the following sources to collect data as follows:

- Secondary data sources: They include books, studies, Arab and foreign sources, publications, regulations and instructions issued by the relevant academic and professional bodies in paper and electronic form.

- Primary data sources: They are collected through a questionnaire consisting of two groups: the first includes the personal data of the respondents; the second includes the items related to the questions of the study according to the following axes: reliability, credibility and security, quality of service, ease of use and interaction of customers. The questionnaire was abstracted and analyzed using the statistical program: Statistical Packages for Social Sciences (SPSS).

\subsection{Population and Sample of the Study}

The study population consists of all 22 bank customers in Jordan, including customers from the public sector, the private sector, the business sector, and retirees. The study used a simple random sample consisting of 180 customers from 12 banks to answer the questionnaire. When reviewing the data, it was found that there were (15) invalid questionnaire for the statistical analysis. Thus, the study sample consisted of (165) valid questionnaires distributed over an online survey, a printed questionnaire.

The highest distribution percentage of the study sample according to the variable of age was (42.4\%) for the age group (25-40 years), while the lowest percentage was $(6.1 \%)$ for the age group (over 55 years). The percentage of males in the study sample was $(59.4 \%)$, while the percentage of females was $(40.6 \%)$. The highest distribution percentage of the study sample according to the educational level was $(40.6 \%)$ for (bachelor), while the lowest percentage was $(2.4 \%)$ for $(\mathrm{PhD})$. The highest percentage of the distribution for the study sample according to the nature of work was $(41.8 \%)$ for the benefit of (free works), while the lowest percentage was $(7.9 \%)$ for the work in (governmental institution). 


\section{$4 \quad$ Results and Discussion}

This section includes the findings of the study which target the extent of customers' interaction in Jordanian banks with mobile banking applications. This will be done by answering the study questions.

\subsection{Second: Findings of applying the simple linear regression test}

The study shows the application of simple linear regression test to study the reliability of customer interaction with mobile banking applications.

Table 1. Shows the application of the analysis of variance anova to study the impact of reliability on customer interaction with mobile banking applications

\begin{tabular}{|c|c|c|c|c|c|c|c|}
\hline Independent variable & Mean & $\begin{array}{c}\text { Value } \\
(\boldsymbol{\beta})\end{array}$ & $\begin{array}{c}\text { Value } \\
(\mathbf{t})\end{array}$ & $\mathbf{R}$ & $\mathbf{R 2}$ & $\begin{array}{c}\text { Value } \\
(\mathbf{F})\end{array}$ & Sig \\
\hline Reliability & 2.09 & 0.94 & 35.28 & 0.94 & 0.88 & 1244.8 & 0.0 \\
\hline
\end{tabular}

Table 1 shows that there is a strong relationship between the reliability and the interaction of customers with mobile banking applications. The value of this relationship was 0.94 , with the value of $\mathrm{R}$ square; reliability is explained by $88 \%$ of the variance in the customer interaction variable. Since the value of $\mathrm{F}$ is equal to 1244.8 at the statistical significance 0.000 , this means that the significance of the regression at $\alpha(0.05)$, and the value of $t$ was (35.28), and the statistical significance was $(0.00)$ which means the significance of the coefficient at the level of significance $(\alpha \leq 0.05)$, it can be said that there is a statistically significant effect of dependence on customer interaction with mobile banking application.

Table 2. Shows the application of the analysis of variance anova to study the impact of credibility and security on customer interaction with mobile banking applications

\begin{tabular}{|l|c|c|c|c|c|c|c|}
\hline Independent variable & Mean & $\begin{array}{c}\text { Value } \\
(\boldsymbol{\beta})\end{array}$ & $\begin{array}{c}\text { Value } \\
(\mathbf{t})\end{array}$ & $\mathbf{R}$ & $\mathbf{R 2}$ & $\begin{array}{c}\text { Value } \\
(\mathbf{F})\end{array}$ & Sig \\
\hline Credibility and security & 2.31 & 0.05 & 0.67 & 0.05 & 0.001 & 0.67 & 0.52 \\
\hline
\end{tabular}


Table 2 shows that there is a weak relationship between credibility and security and the interaction of customers with mobile banking applications. The value of this relationship was (0.05), with the value of $\mathrm{R}$ square, The value of $(\mathrm{F})$ was 0.67 with the statistical significance $(0.52)$, meaning that the regression at the significance level $(\alpha$ $\leq 0.05)$ and the value of $(\mathrm{t})$ was $(0.67)$, with the statistical significance $(0.000)$, which means that the coefficient is also significant at the level of significance $(\alpha \leq 0.05)$, it can be said that there is no a statistically significant impact of credibility and security on customers' interaction with mobile banking applications.

Findings of the application of the regression test to study the quality of service on the interaction of customers with mobile banking applications, as follows:

Table 3. The analysis of variance (anova) for the impact of the quality of service on customer's interaction with mobile banking applications

\begin{tabular}{|c|c|c|c|c|c|c|c|}
\hline Independent variable & Mean & $\begin{array}{c}\text { Value } \\
(\boldsymbol{\beta})\end{array}$ & $\begin{array}{c}\text { Value } \\
(\mathbf{t})\end{array}$ & $\mathbf{R}$ & $\mathbf{R 2}$ & $\begin{array}{c}\text { Value } \\
(\mathbf{F})\end{array}$ & Sig \\
\hline Quality of service & 2.1606 & 0.771 & 15.478 & 0.771 & 0.595 & 239.57 & 0.00 \\
\hline
\end{tabular}

Table 3 shows that there is an intermediate relationship between the quality of service and the interaction of customers with mobile banking applications. The value of this relationship was 0.771 , with the value of $R$ square, The value of $(F)$ was (239.57), with the statistical significance level (0.00), which means the significance of the regression at the level of significance $(\alpha \leq 0.05)$, the value of $(t)$ is equal to $(15,478)$, with the statistical significance level $(0.000)$ which means the significance of the coefficient at the level of significance $(\alpha \leq 0.05)$. It can be said that there is a statistically significant impact of quality of service on customer interaction with mobile banking applications.

Findings of the application of the regression test to study the ease of use on the interaction of customers with mobile banking applications.

Table 4. The analysis of variance (anova) for the impact of ease of use on customer's interaction with mobile banking applications

\begin{tabular}{|c|c|c|c|c|c|c|c|}
\hline Independent variable & Mean & $\begin{array}{c}\text { Value } \\
(\boldsymbol{\beta})\end{array}$ & $\begin{array}{c}\text { Value } \\
(\mathbf{t})\end{array}$ & $\mathbf{R}$ & $\mathbf{R 2}$ & $\begin{array}{c}\text { Value } \\
(\mathbf{F})\end{array}$ & Sig \\
\hline Ease of use & 2.4582 & 0.314 & 4.216 & 0.314 & 0.098 & 17.773 & 0.00 \\
\hline
\end{tabular}


Table 4 shows that there is an intermediate relationship between ease of use and customer interaction with mobile banking applications, where the value of this relationship was $(0.314)$, with the value of ( $\mathrm{R}$ square), it was found that ease of use accounted for $9.8 \%$ of the variance in the interaction of customers with banking applications. Since the value of $(F)$ is equal to 17.773 with the statistical significance 0.00 , meaning the significance of the regression at the level of $\alpha(0.05))$, The value of $(t)$ was 2.4582 , with the statistical significance level $(0.000)$ which means it is significant at the level $(\alpha \leq 0.05)$. There is a statistically significant effect of ease of use on customer interaction with banking applications Mobile.

\section{Conclusion}

This study concludes that mobile banking application user line that is clear and easy to understand enhances customer satisfaction. To achieve this, the mobile banking application should be designed in a way that it allows customers to confirm transactions as they use mobile banking services. The study also concludes that it should be easy for mobile banking customers to recognize their banks' mobile banking application on their phone. This will be achieved if the user interface of customers' mobile banking application is properly designed. Banks have designed systems that are easy to use hence the study concludes that the buttons in the mobile banking application perform the same function always. It is concluded from the study that customers prefer technology and applications that are easy to use hence most of them rarely use applications that are complicated. From this study it is concluded that mobile banking application is able to function as needed all the time hence enhances customer satisfaction. This is done by completing a transaction in full when carrying it out. The study concludes that the mobile banking application enables customers manage their finances better. The level of service quality drawn from a mobile banking application greatly influences the levels of customer satisfaction. The study also concludes that a great mobile banking application ensures confidentiality and security for all transactions. The mobile banking application should also respond quickly to user inputs and transactions initiated. The study concludes that customer's level of ability in using a mobile banking application influences customer satisfaction levels in Jordanian banking industry'. Due to this, most of the customers in Jordan are not very much willing and open to learning the use of mobile banking technologies. The study also concluded that most of customers consider themselves are not highly proficient in the use of smart phone technology hence banks ought to provide support on how their customers should use mobile banking services. The level of availability and features influence customers' decision to use mobile banking services. This means that mobile banking applications should be designed in a way that it can be used by users with low levels of technology proficiency. The study concludes that customers fear using mobile banking technologies hence banks should seek feedback from customers on ways to improve their mobile banking offerings. From the study it is concluded that most customers feel that mobile banking applications are susceptible to fraud hence affecting customer satisfaction. The study also concluded that the ease 
of use of mobile banking services by users influences other customers to use the applications. Customers adopted the use of mobile banking technology as soon as they learnt about it. The bank advertises its online capabilities on various media platforms. The adverts enable banks to make changes to the mobile banking application based on customer feedback.

\section{References}

[1] Yousafzai, S., \& Yani-de-Soriano, M. (2012). Understanding customer-specific factors underpinning internet banking adoption. International Journal of Bank Marketing, 30 (1), 60-81. https://doi.org/10.1108/02652321211195703

[2] Chirani, I., \& Ghofrani, Y. R. (2010, April). Designing a model for explanation of the internet banking acceptance rate. In Information Management and Engineering (ICIME), 2010 the 2nd IEEE International Conference on (pp. 627-633). https://doi.org/1 0.1109/ICIME.2010.5478241

[3] Kim, Y. J., Chun, J. U., \& Song, J. (2009). Investigating the role of attitude in technology acceptance from an attitude strength perspective. International Journal of Information Management, 29(1), 67-77. https://doi.org/10.1016/j.ijinfomgt.2008.01.011

[4] Liao, Z., \& Cheung, M. T. (2008). Measuring consumer satisfaction in internet banking: a core framework. Communications of the ACM, 51(4), 47-51. https://doi.org/1 $\underline{0.1145 / 1330311.1330322}$

[5] Cheng, D., Liu, G., \& Qian, C. (2008, September). On Determinants of User Acceptance of Internet Banking: A Theoretical Framework and Empirical Study. In Advanced Management of Information for Globalized Enterprises, 2008. AMIGE 2008. IEEE Symposium on (pp. 1-5). https://doi.org/10.1109/AMIGE.2008.ECP.20

[6] Cheung, C. M., \& Lee, M. K. (2005, August). Consumer satisfaction with internet shopping: a research framework and propositions for future research. In Proceedings of the 7th international conference on Electronic commerce (p. 327-334). https://doi.org/10.1 $\underline{145 / 1089551.1089612}$

[7] Yee, B. Y., \&Faziharudean, T. M. (2010). Factors affecting customer loyalty of using Internet banking in Malaysia. Journal of Electronic Banking Systems, 2010(2010), 21. https://doi.org/10.5171/2010.592297

[8] Luo, X., Li, H., Zhang, J., \& Shim, J. P. (2010). Examining multi-dimensional trust and multi-faceted risk in initial acceptance of emerging technologies: An empirical study of mobile banking services. Decision Support Systems, 49(2), 222-234. https://doi.org/10. 1016/j.dss.2010.02.008

[9] A. -Rodriguez, P. Pileggi and O.A. Nykänen (2016). Mobile Context-Aware Systems: Technologies, Resources and Applications. International Journal of Interactive Mobile Technologies, Volume 10, Issue 2, 2016. https://doi.org/10.3991/ijim.v10i2.5367

[10] Tommi, L. \& Vesa, K. (2010). The Role of Information in Mobile Banking Resistance. International Journal of Bank Marketing, Vol 28, Issue 5, pp. 372-388.

[11] Carlos T. \& Tiago O. (2016). Performance Impact of Mobile Banking: Using the TaskTechnology Fit (TTF) Approach. International Journal of Bank Marketing, Vol 34, Issue 4, pp. $434-457$.

[12] Minjoon, J. \& Sergio, P. (2016) Examining the Key Dimensions of Mobile Banking Service Quality: An Exploratory Study. International Journal of Bank Marketing, Vol 34 Issue 3, pp. 307 - 326. 
[13] Kennedy Okiro and Jacky Ndungu (2013) The Impact Of Mobile And Internet Banking On Performance Of Financial Institutions In Kenya. European Scientific Journal May 2013 edition vol.9, No.13 ISSN: 1857 - 7881 (Print) e - ISSN 1857- 7431.

[14] Emad Abu-Shanab and Hind Talafha (2015) Internet Banking Adoption in Jordan: The Servqual Extension. 14th International Conference WWW/Internet. ISBN: 978-989-853344-9 (C) 2015.

[15] Satwinderjit Singh, Izzal Asnira Zolkepli, Cheah Wen Ki (2018). New Wave in Mobile Commerce Adoption via Mobile Applications in Malaysian Market: Investigating the Relationship Between Consumer Acceptance, Trust, and Self Efficacy. International Journal of Interactive Mobile Technologies, https://doi.org/10.3991/ijim.v12i7.8964

[16] Malik Khlaif Gharaibeh and Muhammad Rafie Mohd Arshad (2018). Using the UTAUT2 Model to Determine Factors Affecting Adoption of Mobile Banking Services: A Qualitative Approach, International Journal of Interactive Mobile Technologies, https://doi.org/10.3991/ijim.v12i4.8525

[17] Bharti M (2016). Impact of Dimensions of Mobile Banking on User Satisfaction. Journal of Internet Banking and Commerce. vol. 21, no. 1

[18] Ashoka ML, and Ramaprabha D (2018). A study of tam model in the usage of mobile banking services. International Journal of Advanced Research and Development. Volume 3; Issue 1; January 2018; Page No. 109-113.

[19] Shunbo Yuan, Yong Liu, and Ruihong Yao (2014) An investigation of users' continuance intention towards mobile banking in China. Information Development, Vol. 32(1) 20-34 a sagepub.co.uk/journalsPermissions.navidv.sagepub.com.https://doi.org/10.11 $77 / 0266666914522140$

[20] Ashour A. N. Mostafa \& Bilal Eneizan (2013). Factors Affecting Acceptance of Mobile Banking in Developing Countries. International Journal of Academic Research in Business and Social Sciences Vol. 8, No.1, E-ISSN: 2222-6990 ( 2018 HRMARS.

[21] Baolin Sun, Chaohao Sun, Chang Liu, and Chao Gui (2017). Research on Initial Trust Model of Mobile Banking Users. Journal of Risk Analysis and Crisis Response, Vol. 7, No. 1. 13-20. https://doi.org/10.2991/jrarc.2017.7.1.2

[22] Samsudeen S. N. and Fadhilah Bt M. Y. (2018) Sri Lankan Customers' Behavioural Intention to Use Mobile Banking: A Structural Equation Modelling Approach. Journal of Information Systems \& Information Technology (JISIT) ISSN: 2478-0677.

[23] Sultana Rasheda. (2009, December) Mobile banking: Overview of regulatory framework in emerging markets. $4^{\text {th }}$ Communication policy research. South Conference, Negombo, Sri Lanka.

\section{$7 \quad$ Authors}

Dr. Khaled Aldiabat, Assistant Professor, Management Information System Department, College of Administration and Economics, Ajloun National University, Ajloun- Jordan, Research Interests in the field of e-government and knowledge management systems, applications of smart phones, e-commerce and decision support systems. (e-mail: khaledmis@yahoo.com).

Dr. Anwar Al-Gasaymeh, Assistant Professor, Banking and Finance Department, School of Business, Applied Science private University, AmmanJordan, Research Interests in banking efficiency, purchasing power parity and International finance.E-mail: Gasaymeh@yahoo.com; a_gasaymeh@asu.edu.jo). 
Paper-The Effect of Mobile Banking Application on Customer Interaction in the Jordanian Banking ...

Ameer Sardar Kwekha Rashid, Lecturer of Marketing Management Department, College of Administration and Economics, University of Sulaimani, Sulaimani-Iraq, Research Interests in Computer Networks, Computer Science, Knowledge Management Systems and Programming Languages. (e-mail: ameer.rashid@univsul.edu.iq).

Article submitted 23 July 2018. Resubmitted 09 and 16 December 2018. Final acceptance 20 December 2018. Final version published as submitted by the authors. 